\section{RAPID DIAGNOSIS OF VIRUS DISEASES}

\section{T H Flewett}

Regional Virus Laboratory

East Birmingham Hospital

Virus infections which may cause severe or life-threatening illnesses meriting chemotherapy are surveyed. Experience has shown that effective antiviral chemotherapy must be given early in the illness, and so this paper concentrates on the earliest symptoms of the various diseases and on methods leading to rapid diagnosis. This can be made by recognizing virus particles of characteristic morphology, if they occur in large numbers, e.g. rotavirus in diarrhoea. Sensitivity may be enhanced by using immune serum to trap viruses. A variety of very sensitive immunological methods is now available for detecting virus-specific proteins in secretions of the respiratory and alimentary tracts. Monoclonal antibodies help to make these more specific. Virus nucleic acids can also be detected in secretions and cells in situ by hybridization with purified radiolabelled nucleic acid. Virus diseases specifically surveyed include varicella zoster and measles, both very important in immunosuppressed patients; epidemic influenza; and the human papilloma viruses, of which 33 different types are now known, and which cause not only common warts on hands and feet, but also venereally transmitted inapparent papillomes upon the surface of the uterine cervix, often leading to cervical carcinoma. The problems of diagnosis of ecquired immunodeficiency syndrome are reviewed. The eetıology of chronic non-A, non-B hepatitis is still largely obscure, but a retrovirus may be involved. The diagnosis of rabies is also considered.

This review will consider those infections from acquired immunodeficiency syndrome (AIDS) to zoster, likely to become severe enough to warrant expensive and sometimes toxic, dangerous or uncomfortable treatment, survey the earliest symptoms which might lead to a helpful diagnosis and examine the new laboratory methods for identifying the virus responsible.

The process of virus replication is sometimes confined to one or more discrete areas in the cytoplasm. These can usually then be stained and often appear as cosinophilic cytoplasmic inclusions in the light-optical microscope. Sometimes, as in rabies, their structure is quite characteristic, and finding them allows a firm diagnosis to be made. Sometimes intranuclear inclusions can be found; but one cannot tell by light microscopy whether an intranuclear inclusion is caused, for example, by a herpes virus or a papovavirus. Virus-specified proteins can be identified, whether in inclusions or diffused through the cell by serological methods. Virus nucleic acid can also now be detected in some infections. Finally, a virus infection may lead to the release of interferon (IFN) from the cell. The cellular events consequent upon virus infection can be used to detect infection by a wide variety of viruses and will be referred to further under the headings of the different virus diseases.

\section{Methods Leading to Rapid Diagnosis}

Few parts of the body are now out of reach of the tip of an enquiring tube or needle. For instance, the whole alimentary tract is now accessible. Secretions can be taken from the nasopharynx or by bronchoscope. Brain biopsy has been used to diagnose herpes encephalitis by immunofluorescent staining. Of course, the skin is easily accessible and even cardiac muscle biopsy is now possible. Some viruses and methods are listed in Table 1.

\section{Virus Recognition}

Where virus particles of characteristic morphology are present in large numbers, they can at once be recognized by examination of the specimen negatively stained in the electron microscope. For a moderately-sized virus, e.g. rotavirus, the detection limit is about $10^{6}$ virus particles per gram of material, although detection is much easier if there are $10^{8}$ particles. Viruses are normally present in very large numbers in the skin lesions of herpes/varicella zoster. Hepatitis virus particles can be detected in the sera of hepatitis carriers or of patients with acute hepatitis. The recently identified parvovirus can be detected in blood by electron microscopy in the early stages of infection. Viruses having no very characteristic appearance can be identified by immune electron microscopy by mixing the patient's specimen with a specific antiserum and

Table 1

Viruses which can be rapidly recognized in material from patients

\begin{tabular}{|c|c|c|c|c|}
\hline $\begin{array}{l}\text { Electron microscopy } \\
\text { (negative taining) }\end{array}$ & $\begin{array}{l}\text { Enzymo-linked } \\
\text { immunosorbent asary }\end{array}$ & $\begin{array}{l}\text { Reverse possive } \\
\text { Heomagolutination }\end{array}$ & $\begin{array}{l}\text { Imemuno } \\
\text { fluoresecence }\end{array}$ & $\begin{array}{l}\text { Radio } \\
\text { immunassery }\end{array}$ \\
\hline 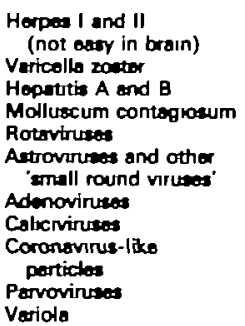 & $\begin{array}{l}\text { Herpes group, including } \\
\text { vericells zoster } \\
\text { Cytomegalovinus } \\
\text { (eepecially for } \\
\text { antibody) } \\
\text { Rotavinuses } \\
\text { Adenoviruses } \\
\text { Hepatitu A and B }\end{array}$ & $\begin{array}{l}\text { Hepatitis B } \\
\text { Rotennuses }\end{array}$ & 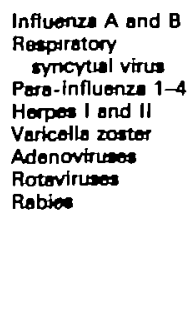 & $\begin{array}{l}\text { Hepatitis } A \text { and } B \\
\text { Respiratory } \\
\text { syncytial virus } \\
\text { Pera-influenze 1-4 } \\
\text { Adenoviruses } \\
\text { Rotoviruses }\end{array}$ \\
\hline
\end{tabular}

Vrus infections for which nuclesc actd hybridizotion mothode, e.g. 'dot-blot' have been used. Papove group, herpes group, ospecrally crtomegalovinuses, hepatitis B and rotoviruses. Other applications, 0.p. for edenovinues and retrovuruses are IBeoly to follow soon 


\section{RAPID DIAGNOSIS OF VIRUS DISEASES $T H$ Flewett}

allowing it to react $-1-3 \mathrm{~h}$ is usually sufficient - and then centrifuging and examining the deposit, negatively stained, in the electron microscope. Sensitivity can be greatly increased by coating with antibody the carbon membrane on the grid. The grid is then floated for about an hour upon a drop of liquid suspected of containing the virus, so that the virus sticks to the antibody. The grid is then washed and negatively stained. This 'fly-paper' method increases the sensitivity of particles detected by up to 1000 -fold. It works very well for plant viruses (for which it was first developed) and usually works well for enteric viruses in human faeces; but for other mammalian material it has not worked so well, perhaps because mammals make antibodies early in the course of infection and these antibodies adhere to the virus particles and block their adhesion to specific antibody upon the grid. When virus has been trapped, it can be identified by labelling with specific antibody.

\section{Immunological and Chemical Methods for Virus Detection}

One can detect virus-specific proteins in nasopharyngeal aspirates of children with acute respiratory tract infections. The cells from these can be centrifuged on to glass slides and are then fixed. The fixed slides can be sent through the post to the laboratory. This method is about as sensitive as virus isolation and a same-day diagnosis can be provided for the clinician. ${ }^{1}$

Radioimmunoassays and immunoenzyme assays have been devised also to detect a variety of virus IgM antibodies, including those of rubella, measles, mumps, tickborne encephalitis, adenovirus and rotavirus. ${ }^{2}$ Monoclonal antibodies help very much in developing a really specific reaction.

Hepatitis $\mathrm{A}$ and $\mathrm{B}$ can be diagnosed by detecting the antigen in faeces and blood respectively by radioimmunoassay. ${ }^{3}$ This method is very sensitive, detecting quantities of antigen in $\mathrm{pg} / \mathrm{ml}$ rather than $\mathrm{ng} / \mathrm{ml}$ concentrations. The method is to attach a 'capture antibody' to the solid phase, which may be a polystyrene bead, or the bottom of the well in a polystyrene microtitre plate. To this is added a suspension of virus. The virus, if present, adheres to the antibody. A second antibody - often nowadays a monoclonal antibody - is added. If virus has adhered, so will the monoclonal antibody. Anti-mouse IgG antibody which has been labelled either with enzyme or with radioactive iodine is then added and the reaction is read, either by developing colour in a chromogenic substrate for the enzyme, or by counting radioactivity in a counter.

Until recently, radioimmunoassay was by far the most sensitive method of detecting virus antigen, but two improvements in the enzyme-linked immunosorbent assay (ELISA) method have come along fairly recently, and offer considerably increased sensitivity. The first relies upon coupling antibody with galactosidase and the use of umbelliferyl $\beta$-galactoside as substrate. The product of the enzyme activity fluoresces in ultraviolet light. Fluorescence can be read by the dark-adapted eye without the use of a spectrophotometer. Sensitivity has recently been increased further by using a peroxidase label. In the presence of hydrogen peroxide, this catalyses the oxidation of luminol or isoluminol and light is emitted. The light emission is enormously enhanced by synthetic firefly $D$-luciferin, and is thus readily detectable; it decays comparatively slowly over several minutes. All one needs is a good luminometer to quantify the light. Other hydroxybenzothiazoles can also be used to enhance light emission by up to 1000 -fold. ${ }^{4-6}$ This, and time-elapsed fluoroimmunoassay, are likely to greatly enhance the sensitivity of detection of virus antigens in material taken directly from patients.

The ELISA system has also been improved by better coupling of enzyme with antibody using a biotin-avidin linkage, which allows the attachment of more enzyme molecules to an antibody molecule than do the conventional methods. ${ }^{6 \mathrm{~b}}$ ELISA tests have the disadvantage in hot countries that enzyme conjugates, even when freezedried, may lose activity in transit.

One can also detect virus antigens by reverse passive haemagglutination. Here, virus-specific antibodies are attached to erythrocytes and, when these are mixed with a suspension of clinical material containing viruses, e.g. hepatitis serum, or supernatants of faeces containing rotaviruses, the virus acts as a 'glue', sticking the antibodies on one erythrocyte to antibodies on another, and so causing agglutination. Freeze-dried antibody-coated cells are more stable than most antibody-enzyme conjugates. Reverse passive haemagglutination works particularly well with some monoclonal antibodies.

A new type of immunoassay called time-resolved fluoroimmunoassay ${ }^{7}$ has recently been developed, mainly in Scandinavia, by the LKB factory in collaboration with Professor Halonen in Finland, and has been used for virus diagnosis. ${ }^{2}$ The basic principle is that, instead of an enzyme, a rare earth element, europium, is attached to antibody. A 'capture' antibody method is used. Virus protein, if present, is trapped by the capture antibody. The virus antigen is then reacted with a second antibody. This, in turn, is reacted with a europium-labelled antiglobulin antibody. After treatment with a fluorescence enhancing solution, the europium is made to emit light, by stimulating it with a very intense xenon flash, or laser pulse.

Virus DNA can be extracted from viruses such as cytomegalovirus (CMV), papilloma etc, and cloned into a bacterial plasmid. The bacteria containing the plasmid can be grown up in great quantity in a medium containing a radioactive label. The radioactive plasmids can then be extracted, the virus DNA fragment cut out of the plasmids with the aid of restriction enzymes and used as a 'probe'. Other methods of making DNA probes are also available. One does not have to use the whole of the nucleic acid; a short nucleotide sequence may be sufficient. This method can also be used for an RNA virus; its RNA can be transcribed to DNA using reverse transcriptase enzyme, and the complementary DNA (cDNA) thus obtained is cloned into a bacterium. The DNA will hybridize with virus RNA in a 'dot-blot' test. This has been used to detect rotavirus double-stranded (ds) RNA in faeces ${ }^{8}$ and the sensitivity compares well with that of the ELISA test. For such tests, virus-containing material is broken up to liberate the nucleic acid, usually by treating it with sodium hydroxide. The nucleic acid can then be blotted to give a spot on a nitrocellulose membrane; the labelled DNA probe is then applied. If virus nucleic acid is present in the membrane, the labelled probe attaches to it. The result can be recorded by an autoradiograph. The probe need not be radioactively labelled; it can be labelled using a biotin-avidin link with an enzyme or fluorescein leading to fluorescence or a coloured enzyme product. The method can be used to detect virus nucleic acid in cells that are not making complete virus, as for example to detect Epstein-Barr (EB) virus DNA sequences in Burkitt lymphoma cells or hepatitis B sequences in hepatocytes. As few as two virus DNA copies per cell can be detected. The basic principles have been well described by Steele. ${ }^{9,10}$

Application of these various methods will be mentioned under the different virus infections described below.

\section{Some Virus Diseases}

\section{Varicella}

Almost always, in previously healthy people, varicella is a comparatively mild disease with an incubation period of about 12-14 days and sometimes a prodromal fever of 1-2 days. 
Occasionally, especially in adults, a severe disease may result with a confluent or semi-confluent rash and a sustained high fever. Rarely, there may be a genuine varicella pneumonia, which is indicated by shortness of breath and cough, sometimes with haemoptysis. X-ray examination reveals diffuse patchy opacity.

In the immunosuppressed, the rash tends to be much worse, and is frequently haemorrhagic, particularly in patients being treated for leukaemia or lymphoma. Pneumonia is comparatively common. ${ }^{11}$ The rash can be quite atypical; antimetabolites prevent the development of the erythematous margin around the varicella vesicles. Low-power microscopy of vesicle fluid reveals large cells with the hypertrophic nuclear structures or inclusion bodies characteristic of herpes type infections. The diagnosis is then usually confirmed by electron microscopic examination of vesicle fluid. The difficulty with pneumonia associated with varicella is to determine whether the pneumonia is caused by the varicella or by some intercurrent agent. Tracheal aspirates or, better, examination of fluid obtained by lung puncture using many of the newer, very sensitive and specific tests for virus and other pathogens may serve to establish the diagnosis. If effective chemotherapy is to be given, a precise diagnosis is essential.

\section{Zoster}

The reactivation of varicella virus which has become latent in the dorsal root ganglia takes place when the patient's immunity falls years after the initial infection, or when the host's immunity is deliberately suppressed. In immunosuppressed subjects, infection may become widespread and serious, with haemorrhagic lesions, and may extend to the central nervous system, causing meningitis or meningoencephalitis. ${ }^{12}$

Laboratory diagnosis is usually unnecessary; the clinical features are obvious enough. Pain over a nerve followed by the eruption of vesicles along it is diagnostic; so is the combination of pain with analgesia over a nerve segment. In the very ill or immunosuppressed, the lesions may be haemorrhagic or otherwise atypical. Diagnosis can be established rapidly by finding characteristic virus particles by electron microscopy in skin lesions and/or in cerebrospinal fluid (CSF) and/or by detecting virus antigen by immunofluorescence or ELISA.

\section{Cytomegalovirus}

About half the population are infected by CMV in the first five years or so of life. Another quarter are infected in their teenage years. (These proportions vary in different communities.) ${ }^{13}$ The infection is usually subclinical, but sometimes there may be a mild rash or a glandular-fever-like syndrome.

Infection is important if it occurs for the first time in pregnant women, when the virus may be transmitted across the placenta to the infant in whom it may cause a range of diseases from the inapparent to a mild illness, sometimes with a slight rash, in which the child becomes 'twitchy' indicating central nervous system (CNS) involvement, to the full-blown syndrome of microcephaly with cerebral calcification and disseminated infection with multiple cytomegalic cells in all the organs of the body. Congenitally infected children excrete virus in considerable quantity in the urine. The so-far insuperable problems of prevention and treatment of CMV infection of fetus and infant have recently been well reviewed. ${ }^{13,14}$

Diagnosis can rarely be made by finding inclusion-bearing cells in the urine, but much more easily by isolating the virus in tissue culture, although two or three weeks often elapse before a cytopathic effect appears. More rapid diagnosis may be made by staining inoculated tissue cultures for immunofiuorescence one or two days after inoculation. ${ }^{15}$ Once a person is infected, the virus genome becomes incorporated into the cell genome, especially in the lymphocytes and probably elsewhere, and persists for life. This carrier state is indicated by finding antibody in the blood. An ELISA test is usually used to screen blood for exchange transfusion to infants and for transfusion into antibody-negative persons being immunosuppressed for kidney or bone marrow transplantation.

Primary infection in the immunosuppressed leads to widespread multiplication of the virus in the body and may cause serious illness in those receiving kidney transplants, though this is less of a problem nowadays than in earlier years when higher doses of immunosuppressants were employed. ${ }^{16,17}$

For children receiving bone marrow transplantation, however, the infection is often severe ${ }^{18.19}$ with pneumonia ${ }^{20}$ and even encephalitis, ${ }^{21}$ and may be lethal. In those previously infected, immunosuppression may cause reactivation and extensive virus replication in many organs. ${ }^{20,22,23}$ Immunosuppression suppresses symptoms too, and usually the only clinical indication of infection is unexplained fever. Although much virus is shed in the urine, an IgM antibody response may not develop. Tissue culture is too slow to give a really rapid diagnosis; and ELISA fails to detect CMV in urine, so a 'dot-blot' detection of the CMV genome in the urine has been developed using radiolabelled CMV DNA probes. This test is now available commercially and gives an answer within $24 \mathrm{~h}$. Different strains of CMV, once isolated in tissue culture, can be differentiated by restriction enzyme analysis of their DNA genomes. ${ }^{17}$ Immunosuppression may light up more than one virus. ${ }^{24}$ Some success has been claimed for an attenuated CMV vaccine in protecting patients to be transplanted. ${ }^{25}$

\section{Epidemic Influenza}

The incubation period is ordinarily 1-2 days. The patient suddenly feels chilly, with headache and malaise and aching of the muscles of the limbs and back, followed frequently by a dry cough often with substernal pain. Occasionally, symptoms are preceded by nasal symptoms and the illness may resemble a 'heavy cold'.

The range of severity varies from subclinical reactions to a fulminant influenza causing death in a few hours, with a haemorrhagic broncho-alveolar pneumonia. In about $10 \%$ of those infected, the disease may begin with vomiting. The average patient's temperature rises rapidly to $38-40^{\circ} \mathrm{C}$ within $24 \mathrm{~h}$ and then, oscillating somewhat, declines to normal by the 3 rd -5 th day. A sudden deterioration with a rise of pulse rate and fever indicates that secondary bacterial pneumonia may be setting in and urgent antibiotic treatment is necessary. In those with pre-existing pulmonary or cardiac disease, influenza may be very much more severe and sometimes fatal; usually death is caused by a secondary bacterial infection, but in cardiac or respiratory cripples, fatal cases of influenza without secondary bacterial infection do occur. In the most severe cases which may suddenly follow what appears to have been a mild disease for one or two days, acute dyspnoea and prostration develop; within a very few hours the patient is dangerously ill, presenting as shocked with tachycardia, pale grey or cyanosed, with a weak pulse and low blood pressure; temperature may be normal, and a thin frothy exudate is seen from the respiratory tract.

In about $25 \%$ of children up to age 10 , influenza may present as croup. In older children, croup is less common and the diagnosis is more easily made: cough is common, the throat may be sore, muscular aching is sometimes severe and fever and headache are prominent.

In clinical diagnosis it is very difficult to distinguish an early case 


\section{RAPID DIAGNOSIS OF VIRUS DISEASES $T H$ Flewett}

of influenza from other varieties of respiratory tract infection, certainly in the early stages, especially when the influenza is not widely prevalent. Infection may rapidly be demonstrated by immunofluorescence or radioimmunoassay in sputum or nasopharyngeal aspirates, especially in children. ${ }^{26}$

\section{Other Respiratory Virus Infections}

Respiratory syncytial virus (RSV) causes a very characteristic syndrome in young children. After an incubation period of about five days, an upper respiratory tract infection begins with snuffles and nasal discharge. Then, in very young children - those under six months are the most severely affected - lower respiratory changes begin. There is a moderate fever, usually with a rapid pulse. The child has difficulty, just as in allergic asthma, in completing expiration. Breathing difficulties cause the child to be admitted to hospital. Mortality is about $2 \%$, higher in children of the poor. The virus infects and causes obstruction of the terminal bronchioles, which in the very young child are very narrow. Breathing usually eases after two or three days and the child can then be sent home. Rapid diagnosis can easily be made by radioimmunoassay (RIA) or immunofluorescent staining of nasopharyngeal aspirates. ${ }^{1,27}$

Pneumonia in infants and young children may be due to infection with $R S V$, para-influenza types $1-3$, influenza virus and occasionally adenoviruses. These can be diagnosed by immunofluorescence on aspirated nasal secretions.

Apart from epidemic influenza, there exists a wide variety of upper and lower respiratory tract infections caused by numerous different viruses which are prevalent especially during the winter. The more severe illnesses, especially in adults may be labelled 'flu'. Viruses responsible are rhinoviruses and respiratory coronaviruses, which usually cause common colds, sometimes with sore throat, and occasionally venture downwards to cause bronchitis. Clinically, nasal obstruction, profuse nasal discharge and absence of fever and myalgia indicate a cold rather than influenza. The distinction is easy enough when dealing with a group of people, but may be impossible in an individual patient.

Several serotypes of adenoviruses, especially types 3 and 7 , cause the syndrome of 'adenopharyngoconjunctival fever' characterized by pharyngitis, fever and conjunctivitis. The virus is easily isolated in most human tissue culture cell lines. Adenovirus type 4 can cause influenza-like outbreaks, especially among military recruits, both in the USA and the UK. Sporadic cases of infection in the general population from adenovirus 4 are rare or, at any rate, rarely diagnosed. The incubation period is about a week. Some serotypes of adenovirus, usually type 8 and occasionally 19 but rarely others, cause acute epidemic keratoconjunctivitis (EKC), especially in shipyards and in hospitals. Virus is transferred by direct contact from person to person, or (in eye hospitals) by instruments, especially tonometers. The incubation period is about 8-10 days and starts with painful follicular conjunctivitis; the cornea becomes oedematous and by slit-lamp microscopy superficial erosions are seen. Photophobia is marked. Pre-auricular lymphnodes are enlarged. Sometimes only one eye is infected; symptoms may follow in the other eye. Rapid diagnosis is by immunofluorescent staining of conjunctival scrapes.

\section{Herpes Simplex Viruses}

Herpes simplex viruses (HSVs) are divided into two types: HSV 1 and HSV 2. Type 1 infects mostly the face and mouth, sometimes also causes lesions upon the hand (whitlow) and is the type usually found in acute encephalitis. Type 2 is usually associated with urogenital infections, but type 2 infections may be found in and around the mouth and type 1 infections in and around the external genitals.

Acute primary herpes simplex in young children can, however, be a serious and severe illness with florid, multiple ulcers and vesicles in and around the mouth, cervical lymphadenitis and a high fever. In children with eczema or in those with extensive burns, a primary herpetic infection can become very severe and may be life-threatening. Infection may be severe in the immunosuppressed. ${ }^{29}$

Herpes simplex keratitis can usually be recognized clinically and confirmed by virological tests. Stromal keratitis results from invasion of the deeper layers of the comea with the herpes virus; much of the damage is caused by a hypersensitivity reaction. ${ }^{30}$

HSV encephalitis is fortunately rare; about one severe case per million of population per year. ${ }^{31}$ The disease is commoner in children than in adults and seems always to be caused by HSV 1. The patient first presents with headache and fever and early malaise. Some patients show early personality changes and about half have fits early in the disease. Headache and fever become worse and the patient goes into coma within a very few days. Localizing signs are often present and indicate a lesion in the temporal lobe on one or other side and most of the signs and symptoms are otherwise caused by cerebral oedema which may be reflected in oedema and swelling of the optic disc. Without treatment, the infection is usually fatal. The differential diagnosis in a child is likely to be a cerebral vein thrombosis, early meningitis or an abscess. In the early stages of the disease, more than 50 cells/cm in the CSF usually points to some other diagnosis; a low sugar level is also likely to indicate a bacterial infection. Workers in the UK and USA used to make a brain biopsy of the temporal lobe to establish a diagnosis beyond doubt before starting treatment. This procedure of itself does not carry a very high risk, but experience has shown that, if treatment is delayed until one is suspicious enough to make a brain biopsy, one has probably waited too long. ${ }^{31}$ It is better to attempt to make a retrospective diagnosis by looking for IgM antibodies appearing in the CSF. These antibodies do not appear early but, as the more modern antiviral agents, especially acyclovir, are comparatively non-toxic, one can afford to 'shoot first and ask questions later'. Inevitably, some patients who do not have herpes encephalitis will thus be treated, and they probably will be none the worse for that. It is important, however, to make certain in patients whose symptoms progress that one is not missing tuberculous meningitis or brain abscess or other treatable cause of symptoms. A computerized axial tomography (CAT) scan or, better still, nuclear magnetic resonance (NMR) scan of the brain helps to establish the diagnosis, but one must repeat that the best results are likely to be obtained in people treated at such an early stage that radiologically detectable lesions are not yet present.

\section{Human Papilloma Viruses}

When a clarified suspension of ground-up warts is examined in the electron microscope, one can often find numerous virus particles. However, since 1976, biochemical and serological investigation of human papillomaviruses has revealed that there are many kinds, all similar in structure, but different in nucleotide and antigenic composition. Different human papillomaviruses may be particularly associated with different types of warts. The earlier work, up to 1980 , was well reviewed by Coleman. ${ }^{32}$

Several different warty syndromes can be recognized. The ordinary warts on the hands and feet of children and adults virtually never undergo malignant transformation and are transmitted by direct or indirect contact through minor abrasions. Virus 
particles in warts are frequently found in extremely large numbers, but mostly in common plantar and palmar warts. In genital warts, virus particles are very much less numerous. Genital warts in both men and women sometimes progress rapidly to very large fungating confluent and infiltrating masses. They are transmitted by sexual contact. Small cervical warts are comparatively common and are frequently found in combination with herpes type 2 infections. Virus diagnosis can be made by nucleic acid 'dot-blot' hybridization. ${ }^{33}$ It may well be that papilloma and herpes viruses act synergistically in the causation of cervical carcinoma; the lesions do sometimes proceed to malignancy. ${ }^{34}$ Immunosuppression is a risk factor. ${ }^{34-40}$ Infection may be passed on to infants passing through the warty birth canal; these infants may subsequently develop laryngeal papillomas. These may have to be treated surgically to allow an adequate airway, but do not usually go on to malignant change, and eventually disappear spontaneously. A rare warty skin disease is epidermodysplasia verruciformis. In this, the patient becomes covered all over with warts, usually flat warts, which develop in early infancy and persist throughout life. The lesions transform into epidermal carcinoma in about a quarter of these patients even in their 20 s and 30 s. Papilloma virus particles can be found in the benign lesions, but not in malignant tumours derived from them.

Human papilloma viruses have been differentiated by extracting their virus-specific DNA, and examining the pattern given by electrophoresis of the DNA fragments after cleavage by restriction enzymes. About 33 different varieties have been recorded. ${ }^{32.38 .41,42}$ Most of these are associated with epidermodysplasia verruciformis. Two or more different DNA varieties have been reported from the same tumour. ${ }^{43}$ The clinical diagnosis is apparent enough, and it is likely that the same antiviral compounds will be effective against all of these viruses.

\section{Acquired Immunodeficiency Syndrome}

This disease was first recognized in early 1981 and some cases occurring in 1979 were diagnosed retrospectively. It is due to a blood-borne infection most frequently transmitted by sexual contact, especially between male homosexuals, by transfusion and by Factor VIII. The origin of the virus (human T lymphocyte virus III - HTLV*) is obscure; one suggestion is that it was originally introduced from Central Africa. ${ }^{44}$ Transmission from mother to baby has been reported. ${ }^{45}$

The syndrome is an underlying cellular immunodeficiency complicated by an opportunistic infection, often pneumocystis pneumonia, or associated with Kaposi's sarcoma in someone under 60 years old. Progressive multifocal leucoencephalopathy has been found in some victims and HTLV III itself may cause CNS lesions. ${ }^{46}$

The disease may be preceded by the extended lymphadenopathy syndrome, defined as unexplained lymphadenopathy in two or more extra-inquinal sites persisting for at least two or three months, and associated usually with fever, malaise, night sweats, weight loss and hepatosplenomegaly. The presence of infection may be indicated by finding IFN- $\alpha$ in the circulation, ${ }^{47}$ but the causative virus can be isolated from lymphocytes ${ }^{4-50}$ and tests for antibody are generally available.

It may yet be possible to detect virus by rapid tests such as competitive radioimmunoassay for immunofluorescence ${ }^{51}$ or with DNA probes for HTLV III or related viruses. ${ }^{52}$

*HTLV III is abo known as lymphedenopathy-aswoctated virus.
Hepatitis

Many different viruses cause acute hepatitis, including hepatitis B (HBV) and the herpes viruses, (see pp. 374-380, this Volume). Hepatitis $A$ is caused by a picornavirus and infection is usually diagnosed using a specific IgM test on acute serum.

$\mathrm{HBV}$ is an important cause of chronic hepatitis, ${ }^{47}$ the pathogenesis of which is complicated - HBV genome may be incorporated into chromosomal DNA ${ }^{34}$ and liver cancer may develop ${ }^{55}$ (see also pp. 374-380, this Volume).

Non-A, non-B hepatitis has been known for the last 10 years or so. As the name suggests, this is a diagnosis by exclusion when tests for hepatitis A and B give negative results. The agents that cause this disease have still not been identified for certain (but see refs. 56 and 57) but may be more important than HBV as a cause of chronic hepatitis. ${ }^{53}$ There are probably at least two different 'nonA, non-B' agents; one giving a short, the other a long incubation period. ${ }^{58} \mathrm{~A}$ water-borne variety also exists. There is no diagnostic method whatever for determining whether one or other or neither of these is responsible, except by inoculation of chimpanzees and by exclusion of HBV, hepatitis A virus, EB virus, CMV and any other virus known to cause hepatitis, e.g. yellow fever virus.

Reverse transcriptase activity is associated with at least one variety of non-A, non-B hepatitis. ${ }^{39}$

\section{Exotic RNA Viruses}

The early diagnosis, clinical or laboratory, of Lassa fever is likely to be extremely difficult. The incubation period is six or seven days. The onset is insidious; sore throat is often the first symptom, followed by generalized muscle aches, making walking painful. These are followed over several days by headache, lassitude, malaise, abdominal pain, loss of appetite and then vomiting and diarrhoea. ${ }^{60}$ Unless there are special reasons for suspecting the infection, the diagnosis is unlikely to be seriously considered before this stage. The most important differential diagnosis is acute subtertian malaria (which can also give a sore throat with white spots upon it) and it is serious negligence to omit examination of the blood film in a febrile patient from West Africa.

The virus is present early in the bloodstream and can be isolated in cell tissue culture; infected cells can be specifically stained by immunofluorescence after about three days' incubation. Such work must only be done in a high-containment laboratory.

Marburg and Ebola fever are clinically similar diseases. The Marburg disease was contracted by persons who came in contact with a consignment of monkeys, which must have been infected from some other source. In the Ebola outbreaks, the virus appears to have been transmitted from person to person, probably by syringe and needle. The incubation period is about seven days. The disease begins with headache, malaise, myalgia, fever and conjunctivitis, followed rapidly by nausea, vomiting and diarrhoea, often haemorrhagic diarrhoea, and a maculopapular rash.

Electron microscopy reveals virus filaments in large numbers in the blood and a rapid diagnosis should certainly be possible by ELISA or one of the newer, more sensitive serological tests for detecting virus antigen, once suitable reagents are available.

Argentine and Bolivian haemorrhagic fevers are caused by Arenaviridae similar to Lassa fever virus. Tickborne Togaviridae cause Kyasanur Forest disease in India and Omsk haemorrhagic fever in the Soviet Union. Other forms of Togaviridae appear to be involved in Congo Crimean haemorrhagic fevers. These are transferred by insect bite or infected blood; aerosols do not seem to be very important. With the Arenaviridae, the source is the urine of infected rodents which carry the virus as a persisting infection. 
Korean haemorrhagic fever (Hantaan virus) is an infection carried by voles which excrete virus in their urine. There appear to be severe and mild varieties. Hantaan virus is widespread over a large part of the northern hemisphere. The symptoms consist of fever, a haemorrhagic rash on the skin, especially upon the chest, raised transaminases and marked renal signs, especially raised blood urea, albuminuria and passage of erythrocytes. Differential diagnosis in the UK is from Weil's disease (caused by Leptospira icterohaemorrhagiae). Rapid diagnostic tests for Hantaan infection are still being developed but diagnosis can be made by finding antibody in the patient's serum a few days after onset.

Treatment of persons with clinical signs of rabies has so far been extremely disappointing. ${ }^{61}$ If any success is ever to be obtained, it is likely that treatment will have to begin at a very early stage of the clinical syndrome. Rabies may be suspected in anyone returning to the UK from abroad with a history of an untreated bite. Early symptoms are anxiety, agitation, depression or psychotic symptoms. Nausea, vomiting, malaise, lethargy and paraesthesia at the site of the bite are also indications. Diagnosis may be made by virus isolation or more rapidly by biopsy of the skin at the edge of the scalp or by corneal scrapings, and then staining the tissue for immunofluorescence using specific antirabies serum. Virus antigen may be detected in saliva by the newer, extremely sensitive, serological tests. Treatment has to be commenced on clinical suspicion. As the disease evolves, the appearance of aphasia and incoordination, paresis and paralysis and in particular hydrophobia with laryngeal spasms when attempting to drink, may make the clinical diagnosis easy but by this stage prospects for successful treatment are bad. ${ }^{61}$

\section{Acute Infectious Diarrhoea}

Viruses, especially rotaviruses, and to a lesser extent adenoviruses, are the commonest infective agents. All age groups are affected but virus diarrhoea is important in young children up to the age of five years and in the aged. ${ }^{62}$ In developed countries, the disease is usually mild and, with expert paediatric care, fatalities are extremely rare. In tropical countries where malnutrition is rife, distances to hospital are great and transport slow, deaths are numerous, mainly from dehydration. The viruses cause diarrhoea by infecting the enterocytes on the tips and sides of the villi of the small intestine. Animal experiments indicate that much virus replication has usually occurred by the time serious diarrhoea has set in. The damaged cells are replaced within 5-8 days by new cells growing up from the crypts of Lieberkuhn; these new cells are incompletely differentiated and are not attacked by rotaviruses, and so the disease is normally self-limiting. ${ }^{63}$

In children suffering from 'combined immunodeficiency syndrome', however, rotavirus diarthoea and virus excretion may persist for months, and is very difficult to treat. ${ }^{64}$

The best available treatment is to give the child oral rehydration solution by mouth in good time - either the WHO formula, or, as favoured by paediatricians in temperate countries, a solution containing a little less sodium; but both work well. Hopes of an effective rotavirus vaccine are rising. So far, there is no effective antiviral compound for rotavirus infection.

\section{REFERENCES}

1 Gardner P, McQuullin J. Rapid virus diagnosis. Application of immunofluorescence. 2nd ed. London: Butterworths, 1980

2 Halonen P, Meurman O, Peterson UG, Ranki M, Lövgren TN-E. New developments in diagnosis of virus infection. In: Kurstak E, Marusyk RG, eds. Control of virus diseases. New York: Dekker, 1984: 501-520

3 Overby LR. Viral diagnosis of hepattis. In: Deinhardt F, Deinhardt J, eds. Viral hepatitis: laboratory and clinical science. New York: Dekker, 1983: 159-198

4 Whitehead TP, Kricka LJ, Carter TJN, Thorpe GHG. Analytical luminescence: its potential in the clinical laboratory. Clin Chem 1979; 25: $1531-1546$

5 Thorpe GHG, Haggart R, Kricka LJ, Whitehead TP. Enhanced luminescent enzyme immunoassays for rubella antibody, immunoglobulin E and digoxin. Biochem Biophys Res Commun, 1984; 119: 481-487

6a Thorpe GHG, Kricka LJ, Gillespie E, et al. Enhancement of the horseradish peroxidase catalysed chemiluminescent oxidation of cyclic diacyl hydrazides by 6-hydroxybenzothiazoles. J Anal Biochem 1985; 145: $96-100$

6b Kendall C, Ionescu-Matiu I, Dreesman GR. Utilization of the biotin/ avidin system to amplify the sensitivity of the enzyme-linked immunosorbent assay (ELISA). J Immunol Methods 1983; 56: 329-339

7 Soini E, Hemmilā I. Fluoroimmunoassay: present status and key problems. Clin Chem 1979; 25: 353-361

8 Pedley S, McCrae MA. A rapid screening assay for detecting individual RNA species in field isolates of rotaviruses. J Virol Methods 1984; 9: 173-181

9 Steel CM. DNA in medicine. The tools. Part 1. Lancet 1984; 2: 908-911

10 Steel CM. DNA in medicine. The tools. Part II. Lancet 1984; 2: 966-968

11 Tobin JO'H. Virus infections in the immunocompromised. In: Waterson AP, ed. Recent advances in clinical virology. 3. Edinburgh: Churchill Livingstone, 1983: 1-17

12 Peterson LR, Ferguson RM. Fatal central nervous system infection with varicella-zoster virus in renal transplant recipients. Transplantation 1984; 37: 366-368

13 Griffiths PD. Congenital cytomegalovirus infection. In: Waterson AP, ed. Recent advances in clinical virology. 3. Edinburgh: Churchill Livingstone, 1983: 57-71
14 Timbury MC. Congenital cytomegalovirus infection: a dilemma. $\mathrm{Br}$ Med J 1984; 289: 712-713

15 Griffths PD, Panjwani DD, Stirk PR et al. Rapid diagnosis of cytomegalovirus infection in immunocompromised patients by detection of early antigen fluorescent foci. Lancet 1984; 2: 1242-1244

16 Pass RF, Whitley RJ, Diethelm AG, Whelchel JD, Reynolds DW, Alford CA. Cytomegalovirus infection in patients with renal transplants: potentuation by antithymocyte globulin and an incompatible graft. J Infect Dis 1980; 142: 9-17

17 Wertheim P, Buurman C, Geelen J, van der Noordaa J. Transmission of cytomegalovirus by renal allograft demonstrated by restriction enzyme analysis. Lancet $1983 ; 1: 980-981$

18 Zaia JA, Forman SJ, Gallagher MT, Vanderwal-Urbina E, Blume KG. Prolonged human cytomegalovirus viremia following bone marrow transplantation. Transplantation 1984; 37: 315-317

19 Meyers JD. Cytomegalovirus infection following marrow transplantation: risk, treatment and prevention. In: Plotkin SA, Michelson S, Pagano JS, Rapp F, eds. CMV: pathogenesis and prevention of human infection. New York: Liss, 1984: 101-117. (Birth Defects; Original Article Series 20)

20 Wade JC, McGuffin RW, Spnngmeyer SC, Newton B, Singer JW, Meyers JD. Treatment of cytomegaloviral pneumonia with high-dose acyclovir and human leukocyte interferon. J Infect Dis 1983; 148: 557-562

21 Cordonnier C, Feulhade F, Vernant JP, Marsault C, Rodet M, Rochant $H$. Cytomegalovirus encephalitis occurring after bone marrow transplantation. Scand J Haematol 1983; 31. 248-252

22 Knapp AB, Horst DA, Eliopoulos G et al. Widespread cytomegalovirus gastroenterocolitis in a patient with acquired immunodeficiency syndrome. Gastroenterology 1983; 85: 1399-1402

23 Friedman AH, Orellana J, Freeman WR, et al. Cytomegalovirus retinitis: a manifestation of the acqured immune deficiency syndrome (AIDS). Br J Ophthalmol 1983; 67: 372-380

24 Dunn DL, Matas AJ, Fryd DS, Simmons RL, Najarian JS. Association of concurrent herpes simplex virus and cytomegalovirus with detrimental effects after renal transplantation. Arch Surg 1984; 119: 812-817

25 Plotkin SA, Smiley ML, Friedman HM et al. Towne-vaccine-induced prevention of cytomegalovirus disease after renal transplants. Lancet 1984; $1: 528-530$ 
26 Sarkkinen HK, Halonen PE, Salmi AA. Detection of influenza A virus by radioimmunoassay and enzyme immunoassay from nasopharyngeal specimens. J Med Virol 1981; 7: 213-220

27 Sarkkinen HK, Halonen PE, Arstila PP, Salmi AA. Detection of respiratory syncytial, parainfluenza type 2 , and adenovirus antigens by radioimmunoassay and enzyme immunoassay on nasopharyngeal specimens from children with acute respiratory disease. J Clin Microbiol 1981; 13: 258-265

28 Rapp F, Howett MK. Herpesviruses and cancer. In: Notkuns AL, Oldstone MBA eds. Concepts in viral pathogenesis. New Yort: Springer-Verlag, 1984: 300-306

29 Wade JC, Day LM, Crowley JJ, Meyers JD. Recurrent infection with herpes simplex virus after marrow transplantation: role of the specific immune response and acyclovir treatment. J Infect Dis 1984; 149 . $750-756$

30 Darougar S, Trehame JD, Monnickendam MA. Herpes simplex infections of the eye. In: Waterson AP, ed. Recent advances in clinical virology. 2. Edinburgh: Churchill Livingstone, 1980: 129-146

31 Longson M, Bailey AS, Klapper P. Herpes encephalitis. In: Waterson $A P$, ed. Recent advances in clinical virology. 2. Edinburgh: Churchil Livingstone, 1980: 147-157

32 Coleman DV. Recent developments in the papovavinuses: the human papilloma viruses. In: Waterson $A P$, ed. Recent advances in clinical virology. 2. Edinburgh: Churchill Livingstone, 1980: 79-88

33 Wickenden C, Steele A, Malcolm ADB, Coleman DV. Screening for wart virus infection in normal and abnormal cervices by DNA hybridisation of cervical scrapes. Lancet 1985; 1: 65-67

34 Lutzner MA, Orth G, Dutronquay V, Ducasse M-F, Kreis H, Crosnier J. Detection of human papillomavirus type 5 DNA in skin cancers of an immunosuppressed renal allograft recipient. Lancet 1983;2: 422.424

35 Chorzelski T, Jarzabek-Chorzelska M, Jablońska S, Orth G, Rzsa G. An immunofluorescence complement-fixation test for detection of human papilloma viruses in various warts and wartlike lesions of epidermodysplasia verruciformis. Arch Dermatol Res 1983; 275: 53-57

36 Schneider V, Kay S, Lee HM. Immunosuppression as a high-risk factor in the development of condyloma acuminatum and squamous neoplasia of the cervix. Acta Cytol 1983; 27: 220-224

37 Gissman L, Boshart M, Dürst M, lkenberg H, Wagner D, zur Hausen H. Presence of human papillomavirus in gental tumors. J Invest Dermatol 1984; 83: 26s-28s

38 Boshart M, Gissman L, Ikenberg H, Kleinheinz A, Scheurlen W, zur Hausen H. A new type of papillomavirus DNA, its presence in genital cancer biopsies and in cell lines derived from cervical cancer. EMBO J 1984; 3: 1151-1157

39 McDougall JK, Nelson JA, Myerson D, Beckmann AM, Galloway DA HSV, CMV, and HPV in human neoplası. J Invest Dermatol 1984; 83: $72 s-76 s$

40 zur Hausen H, Gissmann L, Schlehofer JR Viruses in the etiology of human genital cancer. Prog Med Virol 1984; 30: 170-186

41 Crum CP, Ikenberg H, Richard RM, Gissman L. Human papillomavirus type 16 and early cervical neoplasia. N Engl J Med 1984; 310 . 880-883

42 Ikenberg H, Gissman L, Gross G, Grussendorf-Conen E-I, zur Hausen H. Human papillomavirus type-16-related DNA in genital Bowen's disease and in Bowenoid papulosis. Int $\mathrm{J}$ Cancer 1983; 32: 563-565

43 Ostrow RS, Watts $S$, Bender $M$ et al. Identification of three distinct papillomavirus genomes in a single patient with epidermodysplasia verruciformis. J Am Acad Dermatol 1983; 8: 398-404

44 De Cock KM. AIDS: an old disease from Africa? Br Med J 1984; 289 306-308
45 Ragni MV, Urbach AH, Kieman S et al. Acquired immunodeficiency syndrome in the child of a haemophiliac. Lancet $1985 ; 1: 133-135$

46 Shaw GM, Harper ME, Hahn BH, et al HTLV-III infection in brains of children and adults with AIDS encephalopathy. Science 1984; 227 : 177-181

47 Abbott SR, Buimovici-Klein E, Cooper LZ, Lange M, Briggs M, Weller IVD. Rapid detection of immunoreactive interferon- $\alpha$ in AIDS. Lancet 1984; $1: 564$

48 Gallo RC, Sarin PS, Gelmann EP et al. Isolation of human T-cell leukemia virus in acquired immune deficiency syndrome (AIDS) Science 1983; 220: 865-867

49 Gallo RC, Salahuddin SZ, Popovic M, et al. Frequent detectıon and isolation of cytopathic retroviruses (HTLV-III) from patients with AIDS and at risk for AIDS. Science 1984; 224: 500-503

50 Popovic M, Sarngadharan MG, Read E, Gallo RC. Detection, isolation, and continuous production of cytopathic retroviruses (HTLV-III) from patients with AIDS and pre-AIDS. Science 1984; 224: 497-500

51 Cheingsong-Popov R, Weiss RA, Dalgleish A et al. Prevalence of antibody to human T-lymphotropic virus type III in AIDS and AIDSrisk patients in Britain. Lancet 1984; 2: $477-480$

52 Sodroski J, Rosen C, Wong-Staal F et al. Trans-actıng transcriptional regulation of human $\mathrm{T}$-cell leukemia virus type III long terminal repeat. Science 1984; 227: 171-173

53 Hoofnagle JH, Alter HJ. Chronic viral hepatıtis. In: Vyas GN, Dienstag $\mathrm{JL}$, Hoofnagle JH, eds. Viral hepatitis and liver disease. Orlando: Grune and Stratton, 1984: 97-113

54 Bréchot L, Lugassy C, Dejean A, Pontisso P, Thiers V, Tiollais P Hepatitis B virus DNA in infected human tissues. In: Vyas GN Dienstag JL, Hoofnagle JH, eds. Viral hepatitis and liver disease. Orlando: Grune and Stratton, 1984: 395-409

55 Beasley RP, Hwang L-Y. Epidemiology of hepatocellular carcinoma. In: Vyas GN, Dienstag JL, Hoofnagle JH, eds. Viral hepatitis and liver disease. Orlando: Grune and Stratton, 1984: 209-224

56 Hantz O, Vitvitski L, Trépo C Non A, non B hepatitis: identification of hepatitis B-like virus particles in serum and liver. J Med Virol 1980; 5 73-86

57 Prince AM, Huima T, Willams BAA, Bardina L, Brotman B. Isolation of a virus from chimpanzee liver cell cultures inoculated with sera containıng the agent of non-A, non-B hepatitis. Lancet 1984; 2 : $1071-1075$

58 Zuckerman AJ, Howard CR. Hepatitis viruses of man. London: Academic Press, 1984

59 Seto B, Coleman WG Jr, Iwarson S, Gerety RJ. Detection of reverse transcriptase activity in association with the non- $A$, non-B hepatitis agent(s). Lancet 1984 2: 941-943

60 Casals J, Buckley SM. Lassa fever virus. In: Lehmann-Grube F, ed. Lymphocytic choriomeningitis virus and other arenaviruses. Berlin: Springer-Verlag, 1973: 325-339

61 Merigan TC, Baer GM, Winkler WG et al. Human leukocyte interferon administration to patients with symptomatic and suspected rabies Ann Neurol 1984; 16: 82-87

62 Flewett TH. Clinical features of rotavirus infections. In: Tyrrell DAJ, Kapikian AZ, eds. Virus infections of the gastrointestınal tract New York: Dekker, 1982; 125-145

63 Coelho KIR, Bryden AS, Hall C, Flewett TH. Pathology of rotavirus infection in suckling mice: a study by conventuonal histology, immunofluorescence, ultrathin sections, and scanning electron microscopy. Ultrastruct Pathol 1981; 2: 59-80

64 Pedley S, Hundley F, Chrystie I, McCrae MA, Desselberger U. Genome of rotaviruses isolated from chronically infected immunodeficient children. J Gen Virol 1984; 65: 1141-1150 